Jurnal Jeumpa, 7 (1) Januari - Juni 2020

\title{
PENGARUH PEMAPARAN AIR LIMBAH KELAPA SAWIT TERHADAP KONDISI FISIK TANAMAN BAMBU AIR (Equisetium hymale)
}

\section{THE EFFECT OF OIL PALM WASTE WATER EXPOSURE ON THE PHYSICAL CONDITION OF BAMBOO WATER (Equisetium hymale)}

\author{
Fajriah Mubarak ${ }^{1}$, Abdul L. Mawardi ${ }^{2}$, Elfrida $^{3}$ \\ Jurusan Pendidikan Biologi Fakultas Keguruan Dan Ilmu Pendidikan \\ Universitas Samudra \\ Email : fajriahmubarak98@gmail.com
}

\begin{abstract}
ABSTRAK
Industri kelapa sawit berkembang dengan pesat dan dapat menyebabkan peningkatan limbah industri. Tanaman bambu air (Equisetium hymale) merupakan tanaman hias yang memiliki kandungan silikat yang tinggi memiliki fungsi mengikat partikel logam berat dalam limbah industri. Tujuan dari penelitian yaitu mengetahui dampak pemarapan air limbah kelapa sawit yang mengandung logam berat timbal $(\mathrm{Pb})$ terhadap kondisi fisik tanaman bambu air (Equisetium hymale). Sampel yang digunakan berupa limbah cair kelapa sawit, proses pengambilan sampel diambil pada pengolahan limbah dalam kolam pembuangan limbah pertama dan kolam pembuangan limbah terakhir sebanyak $6000 \mathrm{ml}$, kemudian dimasukan kedalam jerigen plastik. Hasil uji menunjukan bahwa tanaman bambu air mengalami perubahan morfologi batang dari warna hijau menjadi hijau kekuningan yang disebabkan aktifitas kimiawi antara air limbah kelapa sawit yang mengandung senyawa $\mathrm{Pb}$ dengan tanaman.
\end{abstract}

Kata Kunci : Bambu Air (Equisetium hymale), Logam berat, Limbah cair kelapa sawit

\begin{abstract}
The palm oil industry is growing rapidly and can lead to an increase in industrial waste. Water bamboo (Equisetium hymale) is an ornamental plant that has a high silicate content which has the function of binding heavy metal particles in industrial waste. The purpose of this research was to determine the impact of cultivating palm oil waste water containing heavy metal lead $(\mathrm{Pb})$ on the physical condition of aquatic bamboo plants (Equisetium hymale). The sample used is palm oil liquid waste, the sampling process is carried out at the sewage treatment station in the first waste disposal pond and $6000 \mathrm{ml}$ for the final waste disposal pond, then put into plastic jerry cans. The test results showed that water bamboo plants experienced a change in stem morphology from green to yellowish green due to chemical activity between palm oil waste water containing $\mathrm{Pb}$ compounds and plants.
\end{abstract}

Keywords: Water Bamboo (Equisetium hymale), Heavy Metal, Oil Palm Liquid Waste 
Jurnal Jeumpa, 7 (1) Januari - Juni 2020

\section{PENDAHULUAN}

Seiring meningkatnya perkembangan pembangunan industri yang sangat cepat dapat menyebabkan peningkatan limbah industri (Yudo, 2010; Zhang et al, 2013; Eko dkk, 2017). Limbah cair industri menjadi persoalan bagi lingkungan. Limbah yang telah dihasilkan dari berbagai kegiatan industri memberikan dampak negatif terhadap lingkungan, salah satunya berupa pencemaran air yang dapat merusak kesehatan manusia serta berdampak menurunkan daya dukung lingkungan dan terganggunya kualitas air yang menyebabkan kematian organisme air. Air limbah adalah sisa atau hasil akhir dari suatu hasil usaha atau kegiatan yang berwujud cair (Kristanto, 2002; Andhyka, 2015; Rama dan vivi 2019). Diantara banyaknya bahan pencemar lingkungan salah satu yang banyak menarik perhatian adalah logam berat. Logam berat dapat mencemari lingkungan yaitu air, udara maupun tanah yang berasal dari proses alami maupun kegiatan industri yang banyak berasal dari limbah (Widowati, 2008; Lisa, 2013)

Industri yang mengalami perkembangan besar dan pesat adalah industri kelapa sawit. Industri kelapa sawit menghasilkan limbah yaitu berupa limbah padat dan limbha cair. Limbah padat industri kelapa sawit sudah banyak dimanfaatkan salah satunya dapat digunakan sebagai bahan bakar pembangkit listrik, pemanfaatan sebagai pupuk, bioetanol, arang aktif, asap cair hasil pirolisis, bahan bakar, media tanam alternatif dan sebagainya (Andi dkk, 2014; Arif, 2019). sedangkan limbah cair kelapa sawit belum banyak diolah ataupun dikurangi bahan pencemarnya dan limbah cair paling banyak dihasilkan dibandingkan jenis limbah lainnya sedangkan kemampuan alam dalam menerima limbah terbatas sehingga dipastikan bahwa Self purification saat ini telah terlampaui batas (Hidayatullah dkk, 2002; Ibe, dkk, 2014).

Limbah cair kelapa sawit perlu menjadi pusat perhatian, hal ini dikarenakan pada limbah cair terdapat bahan organik tinggi sehingga memiliki kemampuan untuk mecemari tanah dan badan peraiaran serta limbah cair kelapa sawit memiliki potensi besar yang dapat mecemari lingkungan yang didalamnya terdapat logam berat, apabila limbah tersebut tidak dikelola dengan benar dan langsung dibuang kelingkungan dapat menyebabkan terjadinya pencemaran lingkungan (Henry, 2002; Rusmey, 2009; Dedy, dkk, 2010; Sri, 2010). Telah dilakukan beberapa upaya untuk mengatasi pencemaran logam berat namun cara tersebut lebih mahal dan tidak efisien (Onrizal, 2005; Ajeng dkk, 
Jurnal Jeumpa, 7 (1) Januari - Juni 2020

2010). Oleh karena itu diperlukan suatu teknologi dalam mengurangi parameter fisika-kimia limbah cair kelapa sawit dengan fitoremidiasi. Fitoremidiasi juga dapat digunakan dalam mengolah air limbah menggunakan tanaman bambu air (Equisetium hymale). Fitoremidiasi adalah suatu metode degradasi kontaminan dengan memanfaatkan tanaman pada air permukaan dan tanah (Ajeng dkk, 2010; Rony 2010; Manzatu, dkk, 2015).

Tanaman bambu air (Equisetium hymale) terdapat kandungan silikat pada bagian batangnya yang cukup tinggi dan bisa dijadikan sebagai bahan pengikat logam yang terserap oleh tanaman. Selain silikat yang berfungsi mengikat logam berat ada bagian terpenting pada tanaman bambu air (Equisetium hymale) yang bisa mempengaruhi proses fitoremidiasi yang merupakan bagian dari tanaman dan memiliki fungsi memproduksi cairan silikat yaitu serat sklerenkim (Ajeng, 2010; Bambang dkk, 2011).

Penelitian ini dilakukan dalam menurunkan parameter pencemar air imbah kelapa sawit untuk memperoleh pengetahuan dalam pengolahan air limbah kelapa sawit yang mencukupi standar dan tidak mencemari lingkungan (Rama dan Vivi,
2019; Shrestha, dkk, 2019). Pengolahan fitoremidiasi dilakukan karena mudah dalam proses pengolahannya sehingga dapat diaplikasikan oleh industri kelapa sawit serta masyarakat. Pengukuran yang dilakukan pada limbah cair kelapa sawit adalah parameter logam berat Timbal $(\mathrm{Pb})$ dengan melihat baku mutu kadar timbal yang ditetapkan dalam Menteri Lingkungan Hidup Nomor 5 tahun 2014 tentang Baku Mutu Air Limbah.

\section{METODELOGI PENELITIAN}

\section{Alat dan Bahan}

Alat-alat yang digunakan adalah pot, baskom, oven, timbangan, desikator, hot plate, cawan petri, lumping porselen, neraca analitik, deregent, Atomic Absorption Spectrophhotometry (AAS) dan $\mathrm{pH}$ meter. Bahan yang digunakan yaitu Tanaman Bambu Air (Equisetium hymale), limbah cair kelapa sawit, tanah, $\mathrm{H}_{2} \mathrm{O}_{2}$, dan $\mathrm{HNO}_{3}$.

\section{Pengambilan sampel}

Sampel yang digunakan berupa limbah cair kelapa sawit, proses pengambilan sampel diambil pada pengolahan limbah dalam kolam pembuangan limbah pertama dan kolam pembuangan limbah terakhir sebanyak $6000 \mathrm{ml}$, kemudian dimasukan kedalam jerigen plastik. 
Jurnal Jeumpa, 7 (1) Januari - Juni 2020

\section{Prosedur Pelaksanaan}

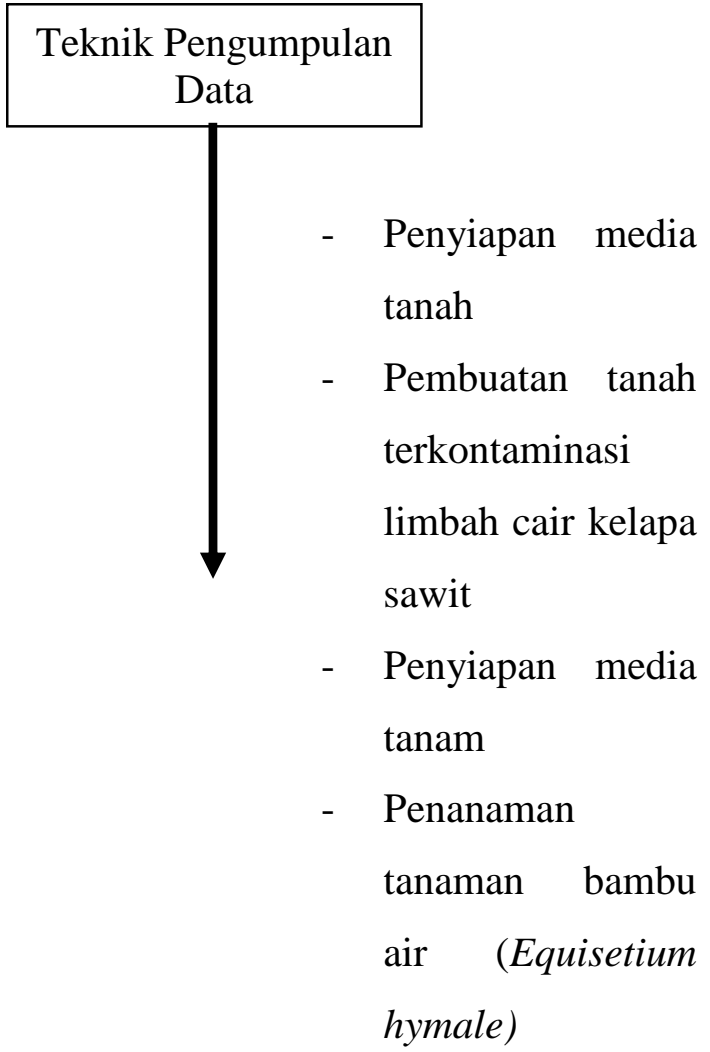

Analisis kondisi fisik tanaman bambu air (Equisetium hymale)

Gambar 1 skema prosedur pelaksanaan

\section{Analisis Data}

Analisis data menggunakan SPSS dengan Uji Normalitas kemudian Uji Homogenitas dan terakhir menggunakan Uji Kruska-wallis.

\section{HASIL DAN PEMBAHASAN}

Penelitian ini menggunakan tanaman bambu air (Equisetium hymale) yang telah diberi perlakuan limbah cair kelapa sawit selama 3 minggu. Pengujian sampel limbah cair kelapa sawit berupa Logam Berat $\mathrm{Pb}$ dilakukan sebelum perlakuan.

Tabel 1. Hasil Uji Karakteristik Air Limbah Kelapa Sawit

\begin{tabular}{|l|l|l|l|}
\hline Parameter & Satuan & Hasil & $\begin{array}{c}\text { Standar } \\
\text { Baku Mutu }\end{array}$ \\
\hline Timbal $(\mathrm{pb})$ & $\mathrm{mg} / \mathrm{l}$ & 0,03 & $0,01^{*}$ \\
\hline $\mathrm{Ph}$ & $\mathrm{mg} / \mathrm{l}$ & 8,36 & 6 sampai 9 \\
\hline
\end{tabular}

Keterangan : $*=$ Diambil dalam Peraturan Lingkungan Hidup No.5 Tahun 2014

Berdasarkan tabel 1 Uji karakter air limbah bertujuan untuk melihat karakter awal kimia dan fisika pada air limbah kelapa sawit, dapat dilihat hasil pemeriksaan dari logam berat timbal $(\mathrm{Pb})$ yaitu $0,03 \mathrm{mg} / \mathrm{l}$, hal ini mengidintifikasi bahwa limbah tersebut masih mengandung logam berat $\mathrm{Pb}$, dimana air limbah kelapa sawit sudah melebihi standart yang telah ditetapkan.

\section{KONDISI FISIK TANAMAN BAMBU} AIR (Equisetium hymale)

Penelitian ini menggunakan tanaman bambu air (Equisetium hymale), yang memiliki karakter panjang dan warna tanaman. Berdsarkan tabel 2.1 karakteristik tanaman perlakuan $\mathrm{P} 0, \mathrm{P} 1$ dan $\mathrm{P} 2$ batang tanaman bambu mengalami pertumbuhan dan perubhan warna pada batang dari warna hijau menjadi hijau kekuningan. 
Tabel 2. Karakteristik Tanaman Bambu Air (Equisetium hymale)

\begin{tabular}{|c|c|c|c|c|c|c|c|}
\hline \multirow{3}{*}{ Perlakuan } & \multicolumn{6}{|c|}{ Waktu (Minggu ke) } & \multirow{3}{*}{$\begin{array}{c}\text { Rata- } \\
\text { rata }\end{array}$} \\
\hline & \multicolumn{2}{|c|}{ Minggu I } & \multicolumn{2}{|c|}{ Minggu II } & \multicolumn{2}{|c|}{ Minggu III } & \\
\hline & $\begin{array}{c}\text { Panjang } \\
(\mathbf{c m})\end{array}$ & Warna & $\begin{array}{c}\text { Panjang } \\
\text { (cm) }\end{array}$ & Warna & $\begin{array}{c}\text { Panjang } \\
(\mathbf{c m})\end{array}$ & Warna & \\
\hline P0 & 25,5 & Hijau & 26,3 & Hijau & 27,2 & Hijau & 26,3 \\
\hline P0 & 26 & Hijau & 26,8 & Hijau & 27,4 & Hijau & 26,7 \\
\hline P0 & 24 & Hijau & 25 & Hijau & 26,3 & Hijau & 25,1 \\
\hline P1 & 27,5 & Hijau & 27,9 & Hijau & 28,4 & $\begin{array}{l}\text { Hijau } \\
\text { kekunin } \\
\text { gan }\end{array}$ & 27,9 \\
\hline P1 & 25 & Hijau & 25,7 & Hijau & 26 & $\begin{array}{l}\text { Hijau } \\
\text { kekunin } \\
\text { gan }\end{array}$ & 25,5 \\
\hline P1 & 30 & Hijau & 31,5 & Hijau & 31,9 & $\begin{array}{l}\text { Hijau } \\
\text { kekunin } \\
\text { gan }\end{array}$ & 31,3 \\
\hline P2 & 31,5 & Hijau & 32,1 & Hijau & 32,8 & $\begin{array}{c}\text { Hijau } \\
\text { kekunin } \\
\text { gan }\end{array}$ & 32,1 \\
\hline P2 & 27 & Hijau & 27,4 & Hijau & 27,8 & $\begin{array}{l}\text { Hijau } \\
\text { kekunin } \\
\text { gan }\end{array}$ & 27,4 \\
\hline P2 & 32 & Hijau & 32,6 & Hijau & 32,9 & $\begin{array}{l}\text { Hijau } \\
\text { kekunin } \\
\text { gan }\end{array}$ & 32,5 \\
\hline \multicolumn{7}{|c|}{ Rata-ra } & 28,3 \\
\hline
\end{tabular}

Kondisi fisik yang diamati dari hasil pengamatan panjang tanaman bambu air (Equisetium hymale) mengalami pertumbuhan yang naik, berdasarkan tabel 2 tanaman bambu air (Equisetium hymale) memiliki panjang rata-rata 28,3 .Menurut (Anam dkk, 2012), tanaman bambu air (Equisetium hymale) mempunyai bentuk fisik tanaman yang berumur 3-4 bulan yang tingginya rata-rata $70 \mathrm{~cm}$ dengan karakter fisik yang kuat, tidak mudah patah batangnya dan hijau. Pada hasil pengamatan warna tanaman bambu air (Equisetium hymale) pada perlakuan P1 dan P2 mengalami perubahan warna pada minggu ketiga, dimana paparan dari limbah cair kelapa sawit mempengaruhi terhadap perubahan warna batang tanaman bambu air (Equisetium 


\section{Jurnal Jeumpa, 7 (1) Januari - Juni 2020}

hymale). Terjadinya perubahan warna ini diakibatkan aktifitas kimiawi antara air limbah dengan tanaman (Ilham, 2019).

Tanaman bambu air (Equisetium hymale) adalah tanaman yang menyerap kontaminan melalui akar kemudian memindahkannya pada batang dan daun atau tanaman ini termasuk jenis phytoextraction. Kandungan air limbah akan diserap oleh tanaman bambu air (Equisetium hymale) melalui akar dan mengikatnya pada bagian batang dengan memakai cairan silikat yang diperoleh dari serat-serat sklerenkim untuk mengikat kandungan timbal. (Ajeng dkk, 2010; Irhamni, 2011; Muslimin, 2012)

Kondisi fisik tanaman secara fisiologi ion logam tidak semuanya terakumulais oleh tanaman, hal ini karena ion logam dapat beralih melalui proses penguapan, dimana oksigen dan ion saling berkaitan membentuk ion-ion baru (Jenny, 2015). Pada minggu pertama tanaman bambu air batangnya masih terlihat hijau, dan ketika pada minggu ketiga tanaman bambu air yang dipaparkan dengan air limbah mulai menunjukan gelaja klorisis, yaitu batangnya mengalami perubahan warna, yang pertama hijau menjadi hijau kekuningan, yang diduga tanaman mengalami toksisitas akibat kandungan logam timbal pada limbah cair kelapa sawit, toksisitas pada tanaman bambu air diduga akibat tanaman keracunan logam berat (Sandy dkk, 2010). Sedangkan tanaman pada reaktor control tidak terdapat perubahan secara fisiologi, hal ini karena tanaman pada reactor control tidak diberi pemaparan air limbah. Perubahan warna pada batang bambu air salah satunya dapat diakibatkan oleh paparan air limbah yang mengandung logam $\mathrm{Pb}$ dalam watu yang lama sehingga penghambatan sintesis klorofil semakin tinggi. Klorisis yang terjadi pada batang tanaman bambu air karena logam berat menghambat kerja enzim yang akan mengkatalis sintesis klorofil (Widiarso, 2011).

\section{KESIMPULAN}

Berdasarkan hasil penelitian dapat disimpulkan bahwa:

1. Limbah cair kelapa sawit mengandung logam $\mathrm{Pb} \quad 0,03 \quad \mathrm{mg} / \mathrm{l}$, dimana sudah melebihi standart yang telah ditetapkan

2. Tanaman bambu air (Equisetium hymale) mengalami perubahan warna pada batangnya dari warna hijau menjadi hijau kekuningan pada batangnya setelah pemaparan air limbah selama 3 minggu. Perubahan warna ini terjadi diakibatkan oleh aktifitas kimiawi antara air limbah yang mengandung $\mathrm{Pb}$ dengan tanaman. 
Jurnal Jeumpa, 7 (1) Januari - Juni 2020

\section{DAFTAR PUSTAKA}

Ajeng, A,B, Wasen,P,Studi,P,Lingkungan T., Teknik, F., Universitas, P., ...Kunci, K. (2010). PENYISIHAN LOGAM BERAT TIMBAL ( $\mathrm{Pb})$ DENGAN PROSES FITOREMIDIASI. Program Studi Teknik Lingkungan Fakultas Teknik Sipil Dan Perencanaan Universitas Pembangunan Nasional “veteran”Jatim, 5(2), 15-23

Arif Setyo Nugroho. 2019. Pemanfaatan Limbah Tempurung Kelapa Sawit Sebagai Campuran Bahan Bakar Diesel. Prosiding SNST-10 Universitas Wahid Hasyim

Anam, Moh Misbahul MS, dkk, 2012. Penurunan Kandungan Logam $\mathrm{Pb}$ dan $\mathrm{Cr}$ Leachate Melalui Fitoremidiasi Bambu Air (Equisetium hymale) dan zeloit . In Press, JKPTB 1(2)

Andhyka septyana dan Hari Rudijanto. 2015. Efisiensi Bambu Air (Equisetium hymale) Sebagai Fitoremidiator Kadar Biological Oxygen Demand Pada Limbah Cair Industri Tahu di Desa Prembun Kecamatan Tambak Kabupaten Banyumas Tahun 2015. Jurnal Keslingmas, 34(1), 124-223

Andy Haryanti dkk, 2014. Studi pemanfaatan limbah padat kelapa sawit. Jurnal Konversi.3(2),20-29

Azmi dkk, 2016. Studi kandungan dan beban pencemaran logam timbal $(\mathrm{Pb})$ pada air balas kapal barang dan penumpang dipelabuhan Tanjung Emas Semarang. Jurnal Kesehatan
Masyarakat (e-Journal), 4(4), 843-846

Bambang Suharto, dkk. 2011. Penurunan Kandungan Logam PB dan CR Leachate Melalui Fitoremidiasi Bambu Air (Equisetium hymale) Dan Zeloit. Jurnal Agrointek, 5(2), 137

Caroline, Jenny, Guido Arron Moa. 2015. Fitoremidiasi Logam Timbal (pb) Menggunakan Tanaman Melati Air (Echinodorus Palafolius) Pada Limbah Industri Pelabuhan Tembaga dan Kuningan : ISBN 978-602-98569. Institusi Teknologi Adhi Tama Surabaya.

Dedy, dkk, 2001. Startup and Operation Of Anaerobic EGSB Reactor treating palm Oil Effluents. J.Environ sci. 20: 658-663

Eko Handayanto, dkk, 2017. Fitoremidiasi dan Phytomining Logam Berat Pencemaran Tanah. Malang : Ub Perss

Hidayatullah, dkk, 2002. Limbah Logam Berat .Surabaya : ITS

Henry Loekito. Teknologi Pengolahan Limbah Industri Kelapa Sawit. Jurnal Teknologi Lingkungan. $3(3), 242-250$

Ibe, I.J, Ogbulie, J.N., Orji, J.C., Nwanze, P.I, Ihejirka, C. \& Okechi, R.N. 2014. Effects Of Palm Oil Mill Effluent (Pome) On SoiL Bakteria and Enzymes at Different Seasons. Internasional Journal Of Current Microbiology and Applied Sciences, 3(10), 928-934 